\title{
The Role of Rain in Dispersal of the Primary Inoculum of Plasmopara viticola
}

\author{
Vittorio Rossi and Tito Caffi
}

Istituto di Entomologia e Patologia Vegetale, Università Cattolica del Sacro Cuore, Via Parmense 84, 29122 Piacenza, Italy. Accepted for publication 19 September 2011.

\begin{abstract}
Rossi, V., and Caffi, T. 2012. The role of rain in dispersal of the primary inoculum of Plasmopara viticola. Phytopathology 102:158-165.

Although primary infection of grapevines by Plasmopara viticola requires splash dispersal of inoculum from soil to leaves, little is known about the role of rain in primary inoculum dispersal. Distribution of rain splashes from soil to grapevine canopy was evaluated over 20 rain periods ( 0.2 to $64.2 \mathrm{~mm}$ of rain) with splash samplers placed within the canopy. Samplers at 40, 80, and $140 \mathrm{~cm}$ above the soil caught 4.4, 0.03, and 0.003 drops $/ \mathrm{cm}^{2}$ of sampler area, respectively. Drops caught at 40 and $80 \mathrm{~cm}$

$(1.5 \mathrm{~cm}$ in diameter) were larger than drops at $140 \mathrm{~cm}(1.3 \mathrm{~cm})$. Leaf coverage by splashed drops, total drop number, and drop size increased with an increase in the maximum intensity of rain $(\mathrm{mm} / \mathrm{h})$ during any rain period. Any rainfall led to infection in potted grapevines placed outside on leaf litter containing oospores, if the litter contained germinated oospores at the time of rain; infection severity was unrelated to rain amount or intensity. Results from vineyards also indicate that any rain can carry $P$. viticola inoculum from soil to leaves and should be considered a splash event in disease prediction systems. Sampling for early disease detection should focus on the lower canopy, where the probability of splash impact is greatest.
\end{abstract}

Plasmopara viticola is the causal agent of grapevine downy mildew, a key disease in all grape-growing areas with frequent rain (34). This oomycete has both sexual and asexual spores, which cause primary and secondary infection cycles, respectively. Oospores are the sexual spores of $P$. viticola. Oospores form within the affected leaf tissue (2), from berry ripening until leaf fall, and overwinter in the leaf litter on or in the soil (21). Because the oospore field population is not coeval, germination occurs gradually during the current (45) and even in the following seasons (13). In spring, oospores germinate in a macrosporangium that releases zoospores in the presence of water; the zoospores are dispersed from the soil to the grape leaves by rain splashes. Once deposited on leaves, zoospores swim toward stomata, form a germ tube, and penetrate the host. The pathogen colonizes the host tissue, and the initial disease symptoms are lesions that are described as "oil spots". First infections are then followed by successive asexual cycles, which are driven by airborne sporangia (4).

Dispersal processes have major effects on both the spatial and temporal dynamics of epidemics (33). In oospore-forming pathogens, disease increases rapidly when rainfall or overhead irrigation causes splash dispersal of primary inoculum from the soil to the aerial parts of plants (42). In contrast, splash dispersal of $P$. viticola primary inoculum has received little attention in the past, probably because downy mildew epidemics were thought to start with infection by only a small number of germinating oospores; the subsequent development of disease was thought to reflect asexual multiplication and secondary infections, without further effect from primary inoculum (34). Recent studies have demonstrated a continuous input of new genotypes to downy mildew epidemics during a prolonged period from May to August (10,25, $26,32,48)$. Therefore, the role of oospores in the development of downy mildew epidemics has been reconsidered (47).

Corresponding author: V. Rossi; E-mail address: vittorio.rossi@unicatt.it

http://dx.doi.org/10.1094/PHYTO-08-11-0223

(c) 2012 The American Phytopathological Society
Since the studies of Baldacci, in 1947, rainfall has been recognized as a key factor for primary downy mildew infection. In the widely known " $3-10$ " rule (3), infection requires the simultaneous occurrence of the following conditions: (i) air temperature $\geq 10^{\circ} \mathrm{C}$, (ii) vine shoots at least $10 \mathrm{~cm}$ long, and (iii) a minimum of $10 \mathrm{~mm}$ of rainfall in 24 to $48 \mathrm{~h}$. This rule has been used as is or with minimal change (e.g., a rainfall threshold of $8 \mathrm{~mm}$ instead of 10 $\mathrm{mm}$ ) for predicting primary infection in many viticultural regions $(15,23,32,43)$. Based on historical records of weather and firstobserved disease in Geneva, NY, a comparable set of simplified rules was developed for use in the DMCAST model $(32,40)$. These rules state that, once vines have five to six unfolded leaves, the first primary infections occur after a rainfall of at least $2.5 \mathrm{~mm}$ coincident with temperatures $\geq 11^{\circ} \mathrm{C}$.

Rain plays several roles in the primary infection by $P$. viticola, including (i) providing moisture for oospore germination (44), (ii) wetting of the soil surface to facilitate the ejection of the zoospores from sporangia and zoospore survival (22), (iii) wetting of the plant surface to enable infection (4), and (iv) dispersal of the zoospores from the ground to the plant by rain splashes. Whereas the first three rain effects have been previously studied, no specific studies have been carried out to define or quantify the role of rainfall in splashing the $P$. viticola inoculum from the soil to the grapevine leaves. Considerable work on splash dispersal has been published, however, for other oospore-forming pathogens such as Phytophthora spp. (42).

The objective of this study was to characterize the role of rain in the splash dispersal of the $P$. viticola primary inoculum from soil to grapevine canopy. The relationship between rain characteristics and rain-splash distribution within the grapevine canopy was determined. Vineyard plants and potted plants were also used to determine the relationship between rain characteristics and infection. The larger practical goal of this study was to collect data to improve disease prediction systems.

\section{MATERIALS AND METHODS}

Three experiments were carried out between 2005 and 2009. In experiment 1 , the distribution of rain splashes from soil to the 
vineyard grape canopy was evaluated during 20 rain periods. In experiment 2 , occurrence of $P$. viticola infection was studied for 61 rain periods by using potted grapevines. In experiment 3 , the relationship between rain characteristics and infection occurrence was studied in commercial vineyards. In this work, "rain periods" are defined as periods of 1.0 to several hours (either uninterrupted or interrupted by some hours without rain) with rainfall $\geq 0.2 \mathrm{~mm}$.

Experiments 1 and 2 were carried out in an experimental vineyard at the University of Piacenza (Northern Italy). This vineyard was 4 years old in 2005 (when these experiments began) and contained Vitis vinifera L. ('Barbera') trained according to a Guyot system, with $2 \mathrm{~m}$ between rows, $1.5 \mathrm{~m}$ between vines within the row, and bare soil as the vineyard floor. A standard weather station (Davis Instruments Corp., Hayward, CA) was installed within the vineyard; air temperature (in ${ }^{\circ} \mathrm{C}$ ), relative humidity (in $\%$ ), total rain (in $\mathrm{mm}$ ), and wind speed (in $\mathrm{m} / \mathrm{s}$ ) and direction were monitored every $10 \mathrm{~min}$. Weather data were used to calculate the following variables for each rain period: (i) number of rain hours, (ii) total rain (in $\mathrm{mm}$ ), (iii) maximum rain intensity (in $\mathrm{mm} / \mathrm{h}$ ), (iv) average rain intensity (in $\mathrm{mm} / \mathrm{h}$ ), (v) average temperature (in ${ }^{\circ} \mathrm{C}$ ), (vi) average relative humidity (in \%), (vii) average wind speed (in $\mathrm{m} / \mathrm{s}$ ), and (viii) wind gusts (in $\mathrm{m} / \mathrm{s}$ ).

Experiment 1. A 5-m-long portion of a vine row was delimited, and three strips were designated on the soil surface: one $50-\mathrm{cm}$-wide central band and two $25-\mathrm{cm}$-wide lateral bands on either side of the central band. The central band roughly corresponded to the canopy projection over the within-row soil, while the lateral bands corresponded to the same area over the betweenrow soil. Twelve "splash-samplers" were installed within the canopy to mimic leaves. A sampler was formed by a stake that supported a board (14 by $14 \mathrm{~cm}$ ). The board, which was fixed to side of the stake, could be inclined from $0^{\circ}$ (i.e., parallel to the stake) to $90^{\circ}$ (parallel to ground) and could be positioned at different heights above the soil. One side of the board had two narrow slots that could hold one filter paper (Gruppo Cordenons S.p.a., Milano, Italy) (12 by $12 \mathrm{~cm}$ ). The samplers were regularly spaced along the row, at $40 \mathrm{~cm}$ above the soil (i.e., the lower leaf layer), $80 \mathrm{~cm}$ above the soil (i.e., the bunch layer), and $140 \mathrm{~cm}$ above the soil (i.e., the higher leaf layer). The board was inclined at $45^{\circ}$ with the side holding the filter paper facing downward (because the stomata are located on the abaxial surface of grape leaves). Each height was represented by four replicate samplers.

Between mid-May and mid-September 2006 and 2008, 20 trials were conducted ( 9 in 2006 and 11 in 2008). Each trial was set up as follows. The soil surface was uniformly covered with either a red (within-row band) or blue (between-row bands) layer $(\approx 1 \mathrm{~cm}$ thick) of iron-hydroxide powder (SIOF S.p.a.; Alessandria, Italy). Powder was reapplied after each rain to ensure uniform coverage of the soil surface. In preliminary tests, this powder showed long persistence on the soil surface and rapidly solubilized in water; based on these characteristics, the layer of powder on the soil surface was able to color all the droplets generated by rain drops falling on the bands, from the beginning until the end of even long rain periods. Filter papers were put into the splash-samplers and exposed until the first rain period had finished. Afterward, the filter papers were removed and analyzed with imagine analysis software (Assess 2.0; American Phytopathological Society Press, St. Paul, MN). The total area covered by red or blue drops and the total area colored were measured (in $\mathrm{cm}^{2}$ ) and expressed as percentages of the total area of the filter paper (i.e., $144 \mathrm{~cm}^{2}$ ); these percentages were used as estimates of the volume of water that impacted the unit area. The number of drops was counted on those filter papers where the drops did not overlap, and the drop diameter was measured (in $\mathrm{mm}$ ) as an estimate of drop size. For those filter papers where the drops overlapped (i.e., $\approx 2 \%$ of the total filter papers), the number of drops was estimated by dividing the area colored by the average size of drops on the other filter papers of the same trial and placed at the same height above the ground.

Experiment 2. Grape leaves were collected in autumn 2006, 2007, and 2008 from the leaf litter in a vineyard (Barbera grape) located in Canneto Pavese (Oltrepo Pavese, Northern Italy); the vineyard had been affected by downy mildew at the end of each season. The presence of oospores was confirmed by examining the leaves by light microscopy ( $\times 40$ to 80 magnification). Leaves with abundant oospores were overwintered outside in plastic net cages placed above the soil at the University of Piacenza (Northern Italy), $5 \mathrm{~m}$ from the weather station; dry leaves at $\approx 600 \mathrm{~g} / \mathrm{m}^{2}$ of soil were arranged in a 3-by-3-m square to produce an "artificial leaf litter".

Groups of three 3-year-old grape plants (Barbera) grown in pots $(30 \mathrm{~cm}$ in diameter) were placed at the center of the artificial leaf litter, with a drip irrigation system that provided the vine roots with water. In total, 61 groups of three plants were exposed in turn to the leaf litter: 20 groups from early March to mid-June 2007; 20 groups from early April to early June 2008; and 21 groups from early March to early July 2009. Before exposure, the plants were grown in a greenhouse; at the time of exposure, they had three to four shoots that were 20 to $30 \mathrm{~cm}$ long. Each group of three plants was exposed until the end of the first rain period (i.e., each group was exposed to inoculum during one rain period). Immediately after rain had finished, pots were placed in a $20^{\circ} \mathrm{C}$ glasshouse with a 12 -h photoperiod; infection by any rainsplashed inoculum that was on the leaves was favored by misting these plants with deionized water for the first $6 \mathrm{~h}$ after they were placed in the glasshouse. In the glasshouse, grapevines escaped any additional source of $P$. viticola inoculum, as demonstrated by control plants grown there. Plants were observed daily to determine the time of lesion appearance and their number.

The presence of germinated oospores in the leaf litter during 61 rain periods was determined indirectly with a bioassay (29). During each rain period, a leaf litter sample was collected and broken into small pieces; $10 \mathrm{~g}$ of leaf fragments were suspended in $50 \mathrm{ml}$ of sterile water and placed in petri dishes. Leaf discs $(20 \mathrm{~mm}$ in diameter) excised from potted Barbera plants grown in a greenhouse and isolated from any external source of $P$. viticola inoculum were floated on the oospore suspension (10 leaf discs per plate) for $12 \mathrm{~h}$, abaxial side down, at $20 \pm 2{ }^{\circ} \mathrm{C}$ under natural light. Afterward, the leaf discs were removed and placed on a layer of wet blotting paper in petri dishes, with the abaxial surface exposed, and incubated at $20^{\circ} \mathrm{C}$ with $12 \mathrm{~h}$ of light and $12 \mathrm{~h}$ of darkness. They were inspected daily for 2 weeks to detect the appearance of disease signs such as sporangiophores. If $P$. viticola sporangiophores appeared on the leaf discs, it was assumed that inoculum (germinated oospores) was present in the leaf litter in that rain period.

Experiment 3. Occurrence of $P$. viticola infection was observed in 120 vineyards in Emilia-Romagna, Northern Italy, during a 5-year period (2005 to 2009, 18 to 30 vineyards each year). Vineyards were selected based on availability of scouting data and the presence of susceptible cultivars. The vineyards selected for this evaluation were representative of the different grapevine-growing areas in terms of soil type, variety, training systems, and cropping regime. They also represent a range in the quantity of overwintering inoculum because of different fungicide spray programs, environmental conditions, and geographical locations. These vineyards were not sprayed with fungicides against downy mildew until the appearance of first seasonal disease symptoms.

Starting from bud break, all leaves on 50 to 100 vines, depending on vineyard size, in each vineyard were inspected every 3 or 4 days to detect when the first lesions (oil spots) appeared on leaves. Because the lesions could have first appeared on any day between the last negative and the first positive scouting, the actual onset of symptoms was expressed as an "onset window". The 
corresponding "infection window" (i.e., the period of probable infection that preceded the onset of symptoms) was calculated for all the vineyards based on the date of symptom onset and the length of one incubation period, which was calculated with temperature-dependent equations (11). Only those 74 vineyards in which only one rain period occurred within the infection window were considered for further analysis.

Daily temperature and rain data were supplied by the agrometeorological regional network for the grids ( 5 by $5 \mathrm{~km}$ wide) in which the vineyards were located. These data were used to calculate the number of consecutive rain days, total rainfall (in $\mathrm{mm}$ ), and average temperature of the rain days (in ${ }^{\circ} \mathrm{C}$ ) during each infection window.

Data analysis. In experiment 1 , a factorial analysis of variance was performed to determine the effect of trial (20 trials) and leaf layer (40, 80, and $140 \mathrm{~cm}$ above the soil surface) on the percentage of the filter paper covered by drops, the number of drops, and the size of drops. Before analysis, the percentage data and drop data were transformed using the arcsin and the natural logarithm functions, respectively, to make variances homogeneous. Pearson's coefficients of correlation were calculated between the total number of drops at 40,80 , and $140 \mathrm{~cm}$ above the ground and the calculated weather variables. In experiment 2 , a Student's $t$ test was used to test the null hypothesis that the rain characteristics of the two groups (i.e., rain periods that did [first group] or did not [second group] lead to $P$. viticola infection) were equal. The equality of variances in the two groups was preliminarily assessed using the Levene's test. Pearson's coefficients of correlation were calculated between the number of downy mildew lesions on leaves and the weather variables. Statistical analyses were performed with PASW Statistics 18.0 (SPSS Inc., Chicago). For experiment 3, inferences were based on consideration of median values and variances.

\section{RESULTS}

Experiment 1. The characteristics of the 20 rain periods considered are shown in Table 1 . These periods occurred between mid-May and mid-September, when plants were in different growth stages; that is, when plants were between stage 12 (shoots $\approx 10 \mathrm{~cm}$ long) of the modified E-L system (16) and stage 41 (after harvest). These rain periods covered a wide range of conditions. They were 1 to $22 \mathrm{~h}$ long, either uninterrupted (10 periods) or interrupted (10 periods), and with total rainfall of 0.2 to $64.2 \mathrm{~mm}$. Maximum rain intensity of each period was 0.2 to $23.6 \mathrm{~mm} / \mathrm{h}$. Average wind speed of the rain hours was 0.3 to $5.0 \mathrm{~m} / \mathrm{s}$, gusts were 3.2 to $>30 \mathrm{~m} / \mathrm{s}$, and wind direction was very variable within the same rain period.

The percent area covered by splashed drops averaged $13.4 \%$ for all rain periods and differed significantly $(P<0.001)$ among rain periods (Fig. 1); rain period accounted for $20 \%$ of total variance in the area occupied by splashed drops. Height of the sampler above the soil also had a significant effect $(P<0.001 ; 37 \%$ of total variance), with $13.3,0.05$, and $0.003 \%$ of the sampler area occupied by drops at 40,80 , and $140 \mathrm{~cm}$ above the soil, respectively. The period-height interaction was also significant $(P<$ $0.001 ; 34 \%$ of total variance) (not shown).

Numbers of splashed drops were significantly $(P<0.001)$ influenced by the rain period (which accounted for $15 \%$ of the total variance), height above the soil (52\% of total variance), and the period-height interaction ( $27 \%$ of total variance). In samplers located $40 \mathrm{~cm}$ above the soil, there were $4.4 \pm 0.5$ drops (mean \pm standard error) per square centimeter of sampler area, with a maximum of $14.4 \mathrm{drops} / \mathrm{cm}^{2}$ (rain period IV) and a minimum of $<1 \mathrm{drops} / \mathrm{cm}^{2}$ (rain periods III, V, IX, XIII, XV, and XVI); on average, $69 \%$ of these drops were splashed from within-row soil and $31 \%$ from the between-row soil (Fig. 2A). At $80 \mathrm{~cm}$ above the ground, there were $0.03 \pm 0.01 \mathrm{drops} / \mathrm{cm}^{2}$ of sampler area (a maximum of $0.21 \mathrm{drops} / \mathrm{cm}^{2}$ in rain period IV), and no drops were caught in 7 of 20 rain periods; $65 \%$ of the drops were splashed from within-row soil and $35 \%$ from between-row soil (Fig. 2B). At $140 \mathrm{~cm}$ above the soil, drops were caught in only six rain periods, with an average of $0.003 \pm 0.001 \mathrm{drops} / \mathrm{cm}^{2}$ of sampler area (a maximum of $0.02 \mathrm{drops} / \mathrm{cm}^{2}$ in rain period XI) (Fig. 2C); $78 \%$ of the drops were splashed from the within-row soil and $22 \%$ from between-row soil.

Drop diameter was 0.3 to $3.7 \mathrm{~mm}$ with a median of $1.3 \mathrm{~mm}$; $\approx 45 \%$ of the drops were 1.0 to $1.5 \mathrm{~mm}$ in diameter (Fig. 3 ). Drops splashed from within-row soil to heights of 40 and $80 \mathrm{~cm}$ were larger (1.54 \pm 0.06 and $1.50 \pm 0.16 \mathrm{~mm}$ in diameter, respectively) than drops splashed to $140 \mathrm{~cm}(1.30 \pm 0.21 \mathrm{~mm}, P=0.035)$ or to drops splashed from between-row soil; the latter drops had an

TABLE 1 . Weather conditions of the 20 rain periods in experiment 1

\begin{tabular}{|c|c|c|c|c|c|c|c|c|c|c|}
\hline Rain period $^{\mathrm{a}}$ & $\begin{array}{l}\text { Period } \\
\text { number }\end{array}$ & $\begin{array}{l}\text { Number } \\
\text { of rain } \\
\text { hours }^{b}\end{array}$ & $\begin{array}{l}\text { Total } \\
\text { rain } \\
(\mathrm{mm})\end{array}$ & $\begin{array}{l}\text { Maximum } \\
\text { rain intensity } \\
(\mathrm{mm} / \mathrm{h})\end{array}$ & $\begin{array}{c}\text { Mean rain } \\
\text { intensity } \\
(\mathrm{mm} / \mathrm{h})\end{array}$ & $\begin{array}{l}\text { Temp } \\
\left({ }^{\circ} \mathrm{C}\right)^{\mathrm{c}}\end{array}$ & $\begin{array}{c}\mathrm{RH} \\
(\%)^{\mathrm{d}}\end{array}$ & $\begin{array}{l}\text { Wind } \\
\text { speed } \\
(\mathrm{m} / \mathrm{s})\end{array}$ & $\begin{array}{l}\text { Gusts } \\
(\mathrm{m} / \mathrm{s})\end{array}$ & Wind direction \\
\hline May, 16 (16-17 h), 2006 & $\mathrm{I}$ & $2 \mathrm{u}$ & 2.0 & 1.4 & 1.0 & 18.6 & 79.5 & 2.4 & 9.7 & SSW,NW \\
\hline May, 22 (14-18 h), 2008 & II & $5 \mathrm{u}$ & 26.6 & 23.6 & 0.2 & 17.4 & 81.0 & 1.6 & 20.9 & N,NW,SSW \\
\hline May, 24 (20 h), 2006 & III & $1 \mathrm{u}$ & 0.2 & 0.2 & 0.9 & 19.6 & 76.0 & 0.2 & 3.2 & $\mathrm{~N}$ \\
\hline June, 7 (9 h)-8 (23 h), 2008 & IV & $4 \mathrm{i}$ & 12.8 & 12.0 & 3.4 & 18.1 & 84.3 & 1.2 & 14.5 & W,NNE,WNW \\
\hline June, 9 (12-16 h), 2006 & $\mathrm{~V}$ & $4 \mathrm{i}$ & 3.4 & 1.6 & 0.2 & 22.7 & 69.3 & 1.2 & 9.7 & SSW,SE,SW \\
\hline June, 12 (1-7 h), 2008 & VI & $5 \mathrm{i}$ & 7.8 & 4.4 & 4.7 & 17.7 & 83.0 & 0.3 & 8 & NW,SSW,SSE \\
\hline June, 13 (2-3 h), 2006 & VII & $2 \mathrm{u}$ & 6.8 & 4.6 & 0.6 & 16.9 & 90.0 & 1.6 & 9.7 & $\mathrm{~N}$ \\
\hline June, 14 (0-7h), 2008 & VIII & $8 \mathrm{u}$ & 28.8 & 13.6 & 5.9 & 14.1 & 84.0 & 5.0 & 20.9 & $\mathrm{~N}$ \\
\hline June, 15 (12-18 h), 2006 & IX & $7 \mathrm{i}$ & 1.6 & 0.4 & 2.9 & 16.0 & 80.4 & 0.5 & 9.7 & SSE,N,NW,NNW \\
\hline June, 17 (4-22 h), 2008 & $\mathrm{X}$ & $7 \mathrm{i}$ & 11.2 & 7.4 & 3.6 & 16.4 & 89.7 & 1.4 & 14.5 & WNW,N,WSW \\
\hline July, 1 (0-5 h), 2006 & $\mathrm{XI}$ & $3 \mathrm{i}$ & 14.2 & 13.2 & 2.9 & 21.0 & 84.3 & 1.6 & 19.3 & N,SSW \\
\hline July, 28 (18-21 h), 2006 & XII & $3 \mathrm{i}$ & 1.8 & 0.8 & 5.3 & 22.5 & 64.7 & 3.7 & 33.8 & WNW,S,N \\
\hline July, 29 (19-20 h), 2008 & XIII & $2 \mathrm{u}$ & 1.6 & 1.4 & 3.2 & 29.3 & 55.5 & 2.4 & 11.3 & SSW,WNW \\
\hline August, 9 (20-23 h), 2006 & XIV & $4 \mathrm{u}$ & 23.6 & 15.8 & 1.6 & 18.8 & 82.5 & 2.0 & 12.9 & NW,SSW,WSW,SE \\
\hline August, $11(6-7$ h), 2006 & $\mathrm{XV}$ & $2 \mathrm{u}$ & 5.8 & 3.2 & 3.2 & 17.4 & 85.5 & 1.6 & 11.3 & $\mathrm{~N}, \mathrm{~S}$ \\
\hline August, $13(22 \mathrm{~h})-14(1 \mathrm{~h}), 2008$ & XVI & $4 \mathrm{u}$ & 4.2 & 1.6 & 1.6 & 16.9 & 80.0 & 3.6 & 24.1 & S,NNW,SW,NNW \\
\hline August, 25 (6-7 h), 2006 & XVII & $7 \mathrm{i}$ & 25.0 & 13.4 & 0.8 & 17.5 & 85.7 & 2.1 & 30.6 & S,N,NNE,NE,NNW \\
\hline August, 29 (23 h)-30 (3 h), 2008 & XVIII & $5 \mathrm{u}$ & 8.4 & 3.0 & 1.1 & 16.3 & 82.2 & 2.1 & 14.5 & S,N,SSE \\
\hline September, 14 (15 h)-15 (19 h), 2006 & XIX & $22 \mathrm{i}$ & 64.2 & 9.0 & 1.4 & 18.5 & 88.9 & 3.4 & 29 & E,ESE, SE,SSE,SSW,SW \\
\hline September, 16 (10 h)-17 (12 h), 2008 & $\mathrm{XX}$ & $7 \mathrm{i}$ & 22.6 & 11.0 & 3.2 & 18.0 & 86.6 & 1.8 & 14.5 & S,WNW,NW \\
\hline
\end{tabular}

a Month, day (hour when the rain period began and ended), year.

${ }^{b}$ Rain hours are hours with rain $\geq 0.2 \mathrm{~mm}$, uninterrupted (u) or interrupted (i) by one or more hours without rain.

c Average temperature (Temp) during the rain period.

$\mathrm{d}$ Average relative humidity $(\mathrm{RH})$ during the rain period. 
average diameter of $1.20 \pm 0.12 \mathrm{~mm}$, and diameter did not differ among the samplers placed at the different heights $(P=0.07)$. Drop size also changed with the rain period $(P<0.001)$ (not shown).

The least splashing occurred during the 1-h rain period III, with $0.2 \mathrm{~mm}$ of rain. During this period, there were $0.04 \pm 0.01$ drops $/ \mathrm{cm}^{2}$ of sampler area with a diameter of $1.44 \pm 0.12 \mathrm{~mm}$ at $40 \mathrm{~cm}$ above ground and no drops at the greater heights. Overall, the volume of water splashed from the soil to the samplers (which was estimated through the percent area of samplers covered by splashed drops) was significantly correlated with maximum rain intensity $(r=0.63, P=0.002, n=20)$. Numbers of drops caught at $40 \mathrm{~cm}$ above the soil were significantly correlated with total rain $(r=0.54, P=0.014)$ and average $(r=0.73, P=0.0002)$ and maximum rain intensity $(r=0.77, P=0.0001)$; those caught at $80 \mathrm{~cm}$ were correlated only with maximum rain intensity $(r=$ $0.45, P=0.046$ ) while those caught at $140 \mathrm{~cm}$ were not correlated with any of the measured rain characteristics. The drop size at $40 \mathrm{~cm}$ was significantly correlated with maximum rain intensity ( $r=0.62, P=0.003)$. Neither the number nor the size of the splashed drops was significantly correlated with the duration of the rain period.

Experiment 2. Germinated oospores were detected in leaf litter in only 23 of the 61 rain periods considered in experiment $2 ; 10$

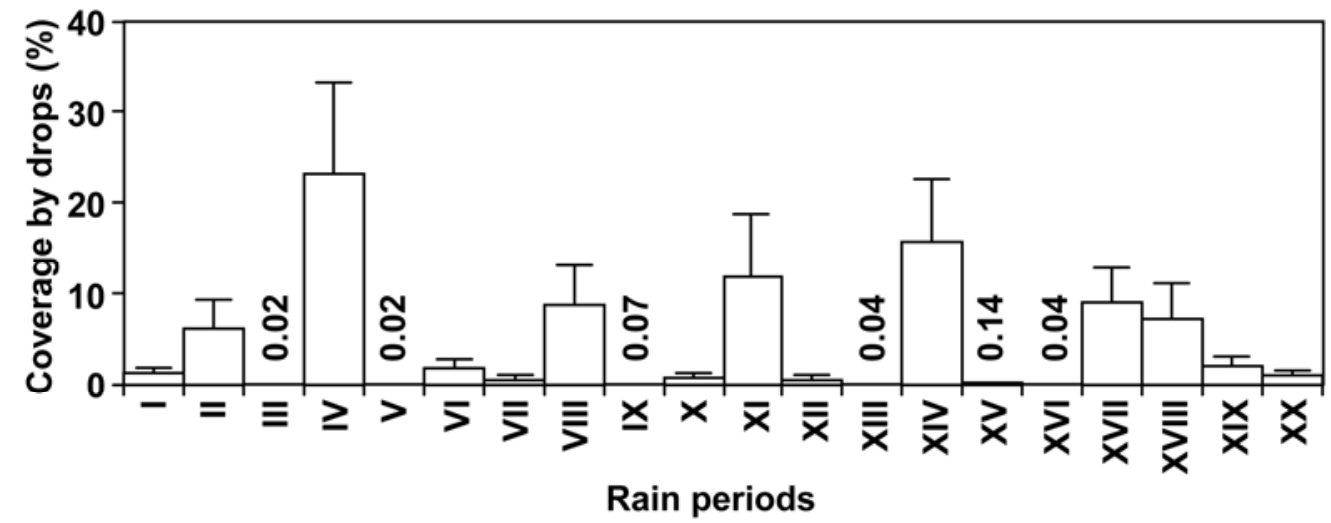

Fig. 1. Coverage by drops splashed from the soil surface to the grapevine canopy during the 20 rain periods of experiment 1 . Coverage is expressed as a percentage of the area covered by drops in splash-sampler placed within the canopy (average of the samplers placed at 40,80 , and $140 \mathrm{~cm}$ above the soil). Whiskers indicate standard error of the mean. Numbers show coverage values too small to visualize.

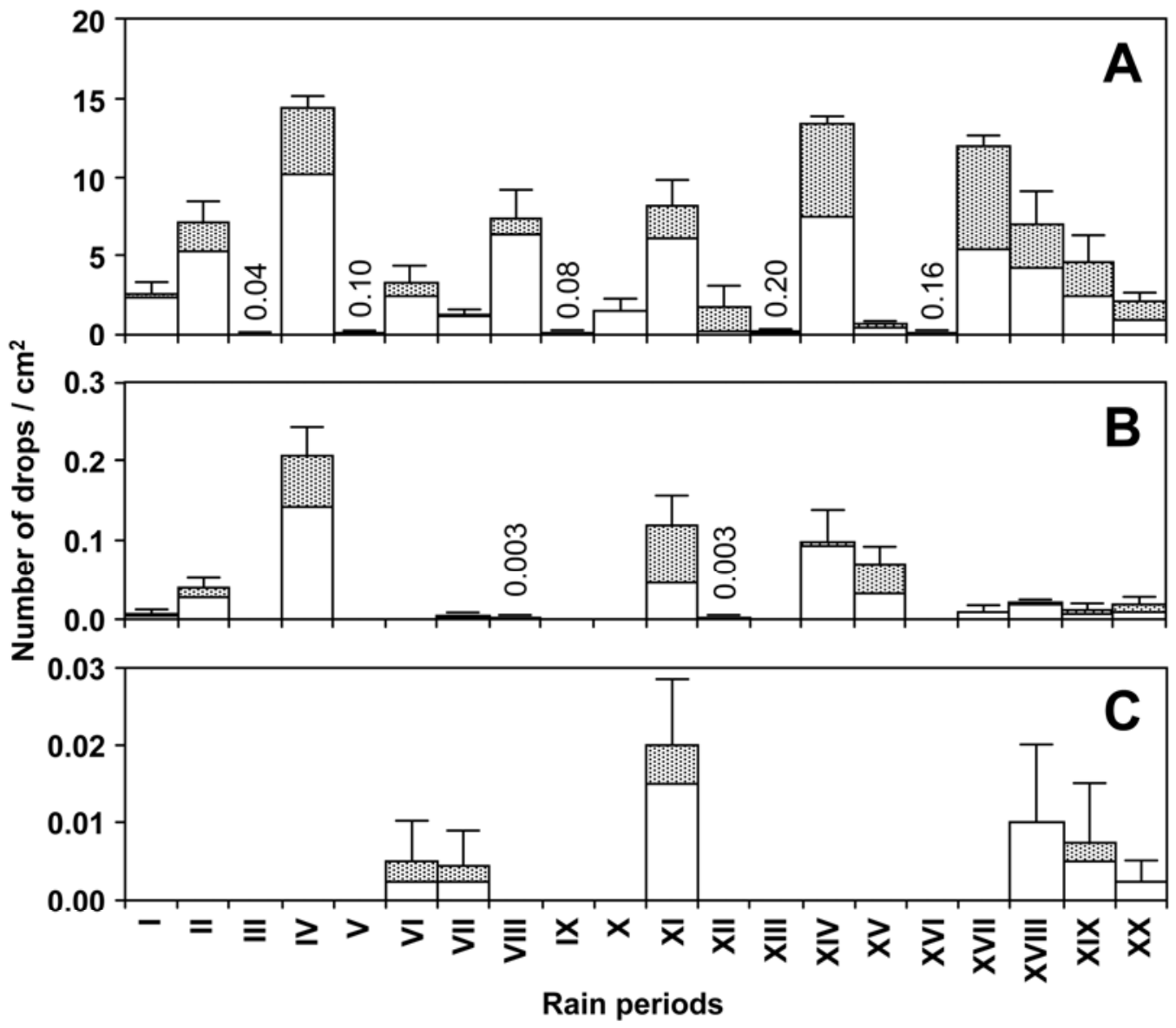

Fig. 2. Number of drops splashed from soil to splash samplers placed within the grapevine canopy at A, 40; B, 80 ; and $\mathbf{C}, 140 \mathrm{~cm}$ above the ground during the 20 rain periods of experiment 1 . White and gray bars indicate drops splashed from within-row soil and between-row soil, respectively. Whiskers indicate standard error of the mean. Numbers show coverage values too small to visualize. Note different scales on y-axis. 
of these rain periods occurred between 14 May and 7 July 2007, 11 occurred between 16 May and 4 June 2008, and two occurred on 6 and 7 July 2009. All 23 of these rain periods resulted in downy mildew infection, with a total of 1 to 24 lesions on the three grapevine plants; the 38 rain periods without germinated oospores did not produce infection. Rain periods that led to infection were 1 to $14 \mathrm{~h}$ long (Fig. 4A) with 0.2 to $56.5 \mathrm{~mm}$ of rain (Fig. 4B) and with a highest rain intensity between 0.2 and $23.6 \mathrm{~mm} / \mathrm{h}$ (Fig. 4C); temperatures were 12.1 to $23.6^{\circ} \mathrm{C}$ (Fig. 4D).

There were no significant differences between the rain features of the 23 rain periods that led to infection and the 38 periods that did not lead to infection (Table 2). In contrast, the average temperature during the rain period was significantly $(P<0.001)$ lower when infection did not occur, even though both temperatures (Table 2) were favorable for infection.

The number of lesions on grape leaves was not significantly correlated to number of rain hours $(P=0.79)$, total rain $(P=$ $0.97)$, maximum rain intensity $(P=0.57)$, or average temperature $(P=0.23)$. For instance, 10 lesions occurred on plants exposed to a 1-h rain period of $0.2 \mathrm{~mm}$, and only 2 lesions occurred on the plants exposed to the highest rain intensity registered $(23.6 \mathrm{~mm} / \mathrm{h})$.

Experiment 3. In the 74 vineyards in which only one rain period occurred within the time of probable infection by $P$. viticola, the first seasonal disease symptoms appeared between day of the year (DOY) 113 and 197 (average DOY = 143). These rain periods were 1 to 11 days long (median of 2 days) (Fig. 5A), with 0.6 to $107.4 \mathrm{~mm}$ of rain (median of $15.2 \mathrm{~mm}$ ) (Fig. 5B) and temperature of 6.2 to $24.9^{\circ} \mathrm{C}$ (median of $16.3^{\circ} \mathrm{C}$ ) (Fig. 5C). The lowest rainfall associated with disease appearance was $0.6 \mathrm{~mm}$ which occurred in the night between 11 and 12 May 2009 and, in 25 of 74 cases, rainfall was $<10 \mathrm{~mm}$ (Fig. 5B).

\section{DISCUSSION}

Rain intensity (millimeters per hour) had a key role in splashing water drops from the ground to grape leaves; increasing intensity resulted in an increased coverage by splashed drops, as well as an increased number and size of the splashed drops. Rain intensity indicates not only the volume of water incident on a unit area per unit time but also the number and size distribution of raindrops as well as their kinetic energy at impaction (41). Previous research has determined that, as rain intensity increases, mean raindrop size increases and more splash drops are formed (51). For a variety of plant pathogens, raindrop size influences both the numbers of spores dispersed and the distance dispersed

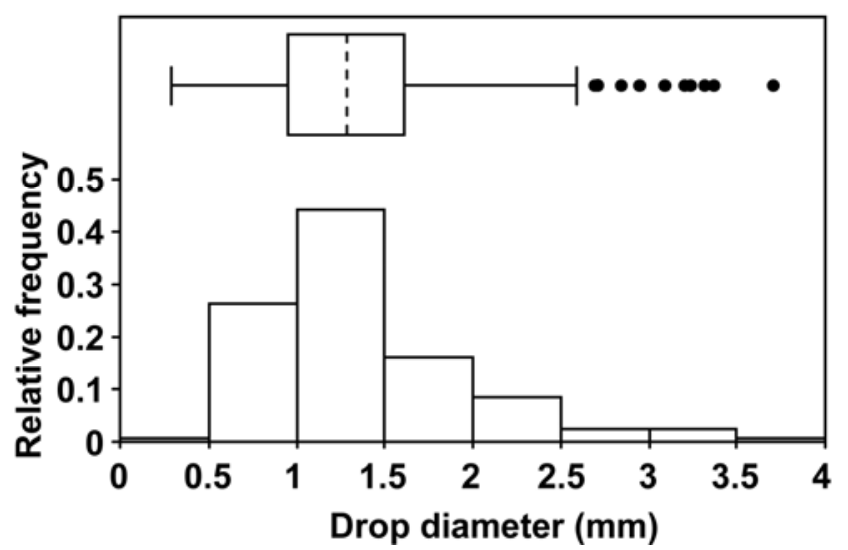

Fig. 3. Size distribution of the drops splashed from soil to splash samplers placed within the grapevine canopy during the 20 rain periods of experiment 1; data include samplers at all three heights. In the box-plot within the figure, the box includes $50 \%$ of the data between the lower and upper quartiles; the band in the box is the median; whiskers extend to the lowest and highest values within the 1.5-interquartile range of the lower and upper quartiles, respectively; and points are outliers.
$(17,19,27,35)$; large raindrops are more effective than small ones because they carry more spores and splash them farther $(18,54,55)$.

The best predictor for the coverage of grape leaves by splashed drops, the total number of splashed drops, and splash drop size was the maximum intensity of rain during the rain period. Numbers of $P$. viticola spores in the drops were not determined in this study but the numbers may be higher in the larger drops generated by the impact of large raindrops during intense rainfall than in the small drops generated in less intense rainfalls (19, 35,56). To our knowledge, this is the first published work on the dispersal to the grapevine canopy of splashing droplets generated by the impact of rainfall on grapevine leaf litter located on vineyard soil. This has been an important gap in our understanding of $P$. viticola epidemiology. Studies carried out in other crops cannot be generalized to grape because both canopy structure and soil surface topography can significantly modify splash magnitude $(1,7,24)$.

Based on the previous considerations, the amount of $P$. viticola inoculum splashed from soil to plant canopy may increase with rain intensity but this does not mean that the probability of infection or disease severity will increase proportionally with rain intensity. Plant canopy size at the time of rain may influence the probability that a splashed droplet is deposited on a susceptible leaf surface; this probability may increase as the leaf area increases and the number of splash droplets increases. In this work, however, rain intensity did not influence the occurrence of infection in potted grapevine plants exposed to isolated rain periods. Similarly, no relationship was found between rain intensity and
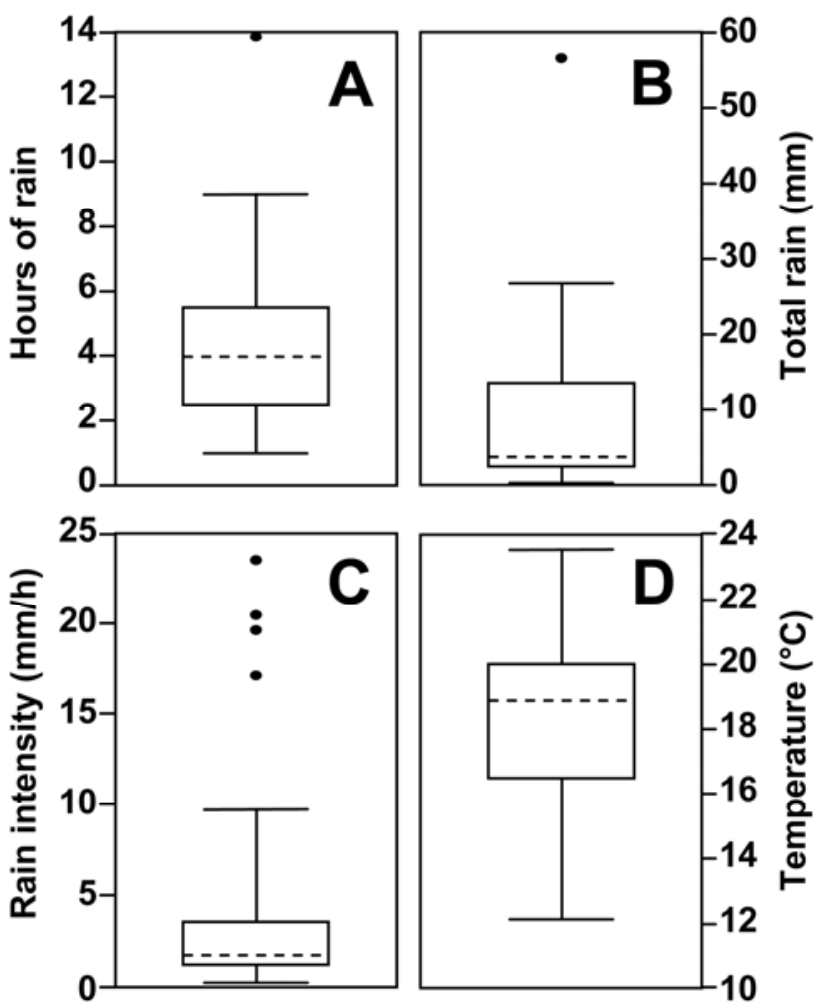

Fig. 4. Features of the rain periods that led to any downy mildew infection on 23 groups of grapevine plants in experiment 2. Grapevine plants were in pots that had been placed in the center of a leaf litter containing Plasmopara viticola oospores. Germinated oospores were detected in the litter in each case. After exposure to any rain period, plants were moved to a $20^{\circ} \mathrm{C}$ glasshouse and wetted for $6 \mathrm{~h}$ to favor infection. A, Number of rain hours; B, total rain; $\mathbf{C}$, maximum rain intensity; $\mathbf{D}$, average temperature of the rain period. Boxes include $50 \%$ of the data between the lower and upper quartiles; the band in the box is the median; whiskers extend to the lowest and highest values within the 1.5-interquartile range of the lower and upper quartiles, respectively; and points are outliers. 
the number of downy mildew lesions that developed on potted grapevine plants exposed to rain. The inoculum dose on the soil at the time of rainfall, the rate of the inoculum removal from the source during the rain event, and wash-off of deposited inoculum from leaves may affect the relationship between disease severity and rain intensity (37).

The results of experiment 2 support the idea that, whenever $P$. viticola inoculum is present on the soil, any rainfall can carry this inoculum to grapevine leaves. It follows that, in the epidemiology of grapevine downy mildew, any rainfall should be considered a splash event. Observations carried out under vineyard conditions in experiment 3 also supported this hypothesis. For instance, downy mildew symptoms were observed on 19 May 2009 following a night-time rain of only $0.6 \mathrm{~mm}$ between 11 and 12 May.

Our results are relevant to grape downy mildew prediction models. The extant models incorporate rain dispersal of the primary inoculum either implicitly or explicitly (33). In the first approach, dispersal is implicitly considered within the effect of rainfall rate on infection occurrence. For instance, in the 3-10 rule (3) and in the disease prediction systems which refer to this rule $(32,39,43)$, there is a threshold of rainfall for downy mildew infection to occur. This accounts for the role of rain in providing moisture for oospore germination, water for zoospore ejection, rain drops for splash dispersal, and free water for leaf wetness. In the EPI model (50), there are three rain thresholds (named critical, minimum, and maximum) that are calculated for each grapevine-growing area based on the average rainfall rate of a 30-year climatic series.

An alternative is to consider splash dispersal explicitly, as a component of the processes leading to infection (33). In the case of $P$. viticola, DMCast and Vitimeto-Plasmopara prediction systems $(6,32)$ include daily rainfall rates as a specific component of the infection processes that lead to primary infection. The model of Rossi et al. (46) integrates all the stages of the infection process at hourly intervals, and specifically includes the splash events of the inoculum from the ground to grapevine leaves. In this model, a splash event is defined as any rain that occurs when there is viable inoculum on the ground, regardless of rainfall rate or rain intensity. Based on the results of our work, the disease prediction systems that include splash dispersal implicitly or that use a rainfall threshold for the occurrence of downy mildew infection should be reconsidered because they underestimate the probability of infection. This inaccuracy in modeling the role of rain in inoculum dispersal is probably one of the reasons why predictions provided by some of these models are not robust $(8,20,53)$. The robustness of the model of Rossi et al. (46) under different environmental conditions $(10,12)$ and in a disease warning system (9) confirms the advantages of explicitly expressing all the biological processes involved in downy mildew infection.

Results from the present work should be incorporated into disease prediction systems either deterministically or probabilistically. In the deterministic approach, models may consider that, whenever inoculum is available on the soil, any rainfall is able to produce splashing droplets that may disperse the inoculum from soil to leaves. In the probabilistic approach, models could contain a function for the probability that splashed droplets will reach grapevine leaves. A probability approach was used for predicting dispersal of airborne ascospores (12) and conidia (14) of Erysiphe necator, the grapevine powdery mildew fungus. Development of this probability function for $P$. viticola inoculum requires further studies and should include information on extension of the leaf area, its vertical profile, and specific data on vertical distribution and spectrum of droplets as affected by rain features.

Results of our work can also be used to improve the design of leaf sampling procedures for early disease detection in the vineyard. Leaf sampling has substantial practical value in disease warning systems $(15,28,38)$. The first seasonal disease signs usually appear at very low incidence (30) and are randomly distributed in the vineyard (36); secondary lesions, however, are highly aggregated $(5,36)$. The detection of rare individuals, which is the precursor to effective management of these individuals in several plant protection contexts, requires powerful sampling strategies, especially when sampling efforts are limited by resources (52). Sampling requires time and money and provides information that is subject to uncertainty (31).
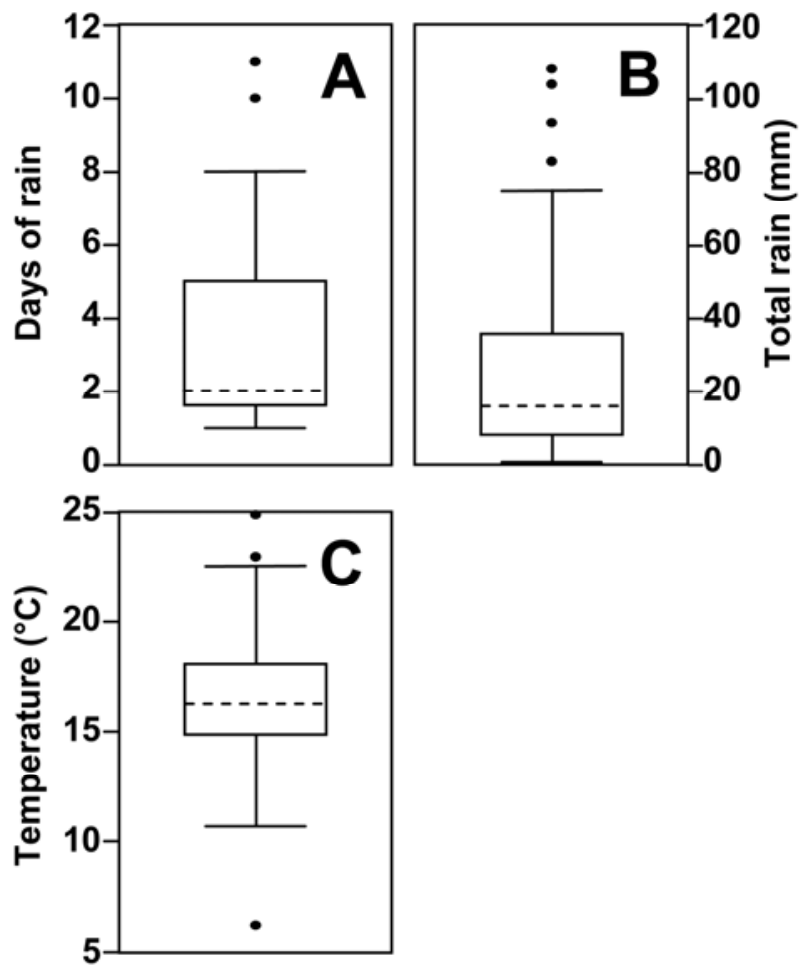

Fig. 5. Features of the rain periods that resulted in downy mildew infection in 74 commercial vineyards from 2005 to 2009 in experiment 3. A, Number of consecutive rain days; $\mathbf{B}$, total rain; and $\mathbf{C}$, average temperature of the rain period. Boxes include $50 \%$ of the data between the lower and upper quartiles; the band in the box is the median; whiskers extend to the lowest and highest values within the 1.5-interquartile range of the lower and upper quartiles, respectively; and points are outliers.

TABLE 2. Weather conditions during 61 rain periods in experiment 2 in which potted grapevine plants were exposed to leaf litter containing Plasmopara viticola oospores that either caused or did not cause downy mildew infection on leaves

\begin{tabular}{lccccc}
\hline Infection occurrence $^{\mathrm{a}}$ & Number of rain periods & Number of rain hours ${ }^{\mathrm{b}}$ & ${\text { Total rain }(\mathrm{mm})^{\mathrm{b}}}$ & ${\text { Maximum rain intensity }(\mathrm{mm} / \mathrm{h})^{\mathrm{b}}}^{\text {Temperature }\left({ }^{\circ} \mathrm{C}\right)^{\mathrm{b}}}$ \\
\hline Yes & 23 & $4.7(0.76)$ & $9.9(2.79)$ & $5.3(1.53)$ & $18.3(0.54)$ \\
No & 38 & $7.6(1.36)$ & $10.8(2.34)$ & $3.4(0.66)$ & 0.264 \\
$P$ & $\ldots$ & 0.074 & 0.809 & $<.7(0.61)$ & $<0.001$ \\
\hline
\end{tabular}

${ }^{a}$ Healthy plants were placed in the center of a leaf litter containing oospores until the end of the first rain period, during which they may have received rainsplashed zoospores (released by germinated oospores of $P$. viticola in the leaf litter); plants were then removed and wetted to favor infection, and leaves were assessed for disease symptoms. Presence of germinated oospores in the leaf litter was determined for each rain period by a bioassay; there were no germinated oospores when infection did not occur. $P$ is the probability level of the null hypothesis that the two groups (no and yes infection) belong to populations with the same average.

b Values are averages of 23 and 38 rain periods while values in parentheses are standard errors. 
Seem et al. (49) developed a procedure for early downy mildew detection based on vineyard scouting on a preselected number of sampling units, which are the lateral half of the canopy of four contiguous plants. To reduce the number of sampling units and, thus, reduce expenditure of time and money while maintaining an acceptable level of confidence, they proposed that scouts should not randomly select sampling units but should, instead, stratify the vineyards into areas of different disease risk and should search those areas with the highest risk of disease occurrence (49). Based on the current study, sampling for early disease detection may be faster and more accurate if it focuses on the lower canopy layer, where the probability of splash impact is greatest.

\section{ACKNOWLEDGMENTS}

V. Rossi and T. Caffi contributed equally to this article. T. Caffi carried out part of this work within the Doctoral School on the Agro-Food System (Agrisystem) of the Università Cattolica del Sacro Cuore (Italy).

\section{LITERATURE CITED}

1. Al-Durrah, M. M., and Bradford, J. M. 1982. The mechanism of raindrop splash on soil surfaces. Soil Sci. Soc. Am. J. 46:1086-1090.

2. Arens, K. 1929. Untersuchungen über Keimung und Zytologie der Oosporen von Plasmopara viticola (Berl. et De Toni). Jahrb. Wiss. Bot. 70:57-92.

3. Baldacci, E. 1947. Epifitie di Plasmopara viticola (1941-46) nell'Oltrepó Pavese ed adozione del calendario di incubazione come strumento di lotta. Atti Ist. Bot. Lab. Crittogam. 8:45-85.

4. Blaeser, M., and Weltzien, H. C. 1979. Epidemiologische Studien an Plasmopara viticola zur Verbesserung der Spritzterminbestimmung. Z. Pflanzenkr. Planzenschutz 86:489-98.

5. Blaise, P., Schumacher, P., and Gessler, C. 1994. Forecast of downy mildew on grapevine: Sampling disease severity in a vineyard. Pages $42-$ 47 in: Proc. First Int. Workshop Grapevine Downy Mildew Model. D. M. Gadoury and R. C. Seem, eds. Cornell University, Geneva, NY.

6. Bleyer, G., Kassemeyer, H. H., Krause, R., Viret, O., and Siegfried, W. 2008. VitiMeteo Plasmopara-Prognosemodell zur Bekämpfung von Plasmopara viticola (Rebenperonospora) im. Gesunde Pflanz. 60:91-100.

7. Brandt, C. J. 1989. The size distribution of through fall drops under vegetation canopies. Catena 16:507-524.

8. Caffi, T., Rossi, T., Cossu, A., and Fronteddu, F. 2007. Empirical vs. mechanistic models for primary infections of Plasmopara viticola. Bull. OEPP 37:261-271.

9. Caffi, T., Rossi, V., and Bugiani, R. 2010. Evaluation of a warning system for controlling primary infections of grapevine downy mildew. Plant Dis. 94:709-716.

10. Caffi, T., Rossi, V., Bugiani, R., Spanna, F., Flamini, L., Cossu, A., and Nigro, C. 2009. A model predicting primary infections of Plasmopara viticola in different grapevine-growing areas of Italy. J. Plant Pathol. 91:535-548.

11. Caffi, T., Rossi, V., and Carisse, O. 2011. Evaluation of a dynamic model for primary infections caused by Plasmopara viticola on grapevine in Quebec. Plant Health Progress. Online publication. doi:10.1094/PHP2011-0126-01-RS

12. Caffi, T., Rossi, V., Legler, S. E., and Bugiani, R. 2011. A mechanistic model simulating ascosporic infection by Erysiphe necator, the powdery mildew fungus on grapevine. Plant Pathol. 60:522-531.

13. Caffi, T., Rossi, V., and Lusitani, M. 2011. Long-term survival of Plasmopara viticola oospores. IOBC/WPRS Bull. 66:111-114.

14. Calonnec, A., Cartolaro, P., Naulin, J. M., Bailey, D., and Langlais, M. 2008. A host-pathogen simulation model: Powdery mildew of grapevine. Plant Pathol. 57:493-508.

15. Carisse, O., Bacon, R. Lasnier, J. Lefebvre, A., Levasseur, A., Rolland, D., and Jobin, T. 2010. Grape disease management in Quebec. Agriculture and Agri-Food Canada, Quebec, QC, Canada.

16. Coombe, B.G. 1995. Adoption of a system for identifying grapevine growth stages. Aust. J. Grape Wine Res. 1:104-110.

17. Fitt, B. D. L., and McCartney, H. A. 1986. Spore dispersal in splash droplets. Pages 87-104 in: Water, Fungi and Plants. G. Ayres and L. Boddy, eds. Cambridge University Press.

18. Fitt, B. D. L., McCartney, H. A., Creighton, N. F., Lacey, M. E., and Walklate, P. J. 1988. Dispersal of Rhynchosporium secalis conidia from infected leaves or straw by simulated rain. Ann. Appl. Biol. 112:49-59.

19. Fitt, B. D. L., McCartney, H. A., and Walklate, P. J. 1989. The role of rain in dispersal of pathogen inoculum. Annu. Rev. Phytopathol. 27:241-270.
20. Fronteddu, T., and Cossu, A. 2002. Indagine sull'affidabilità del modello EPI Plasmopara nei vigneti della Sardegna orientale. Atti II Giornate di Studio "Metodi numerici, statistici e informatici nella difesa delle colture agrarie e delle foreste: Ricerca e applicazioni" Pisa 20/23 maggio 2002. Not. Prot. Piante 15:73-84.

21. Galbiati, C., and Longhin, G. 1984. Indagini sulla formazione e sulla germinazione delle oospore di Plasmopara viticola. Riv. Patol. Veg. 20:66-80.

22. Galet, P. 1977. Les Maladies et les Parasites de la Vigne. Tome I, Le Maladies Due à des Végétaux. Le Paysan du. Midi, Montpellier, France.

23. Gehmann, K. 1987. Untersuchungen zur Epidemiologie und Bekämpfung des Falschen Mehltaus der Weinrebe, verursacht durch Plasmopara viticola. Ph.D. thesis, University of Stuttgart-Hohenheim, Germany. (In German)

24. Ghadiri, H., and Payne, D. 1988. The formation and characteristics of splash following raindrop impact on soil. J. Soil Sci. 39:563-575.

25. Gobbin, D., Jermini, M., Loskill, B., Pertot, I., Raynal, M., and Gessler, C. 2005. Importance of secondary inoculum of Plasmopara viticola to epidemics of grapevine downy mildew. Plant Pathol. 54:522-534.

26. Gobbin, D., Pertot, I., and Gessler, C. 2003. Identification of microsatellite markers for Plasmopara viticola and establishment of high throughput method for SSR analysis. Eur. J. Plant Pathol. 109:153-164.

27. Gregory, P. H. 1973. The Microbiology of the Atmosphere. John Wiley \& Sons, New York

28. Hill, G. K. 1991. Plasmopara Risk Oppenheim-a deterministic computer model for the viticultural extension service. Not. Mal. Piante 111:182-194.

29. Hill, G. K 1998. Studies on the germination of Plasmopara viticola oospores with a floating disc test. Integrated control in viticulture. IOBC/WPRS Bull. 21:1

30. Hill, G. K., and Breth, K. 1997. Severe primary infections of Plasmopara viticola - a plant pathologist's nightmare. Vitic. Enol. Sci. 52:150-151.

31. Hughes, G. 1999. Sampling for decision making in crop loss assessment and pest management: Introduction. Phytopathology 89:1080-1083.

32. Kennelly, M. M., Gadoury, D. M., Wilcox, W. F., Magarey, P. A., and Seem, R. C. 2007. Addressing the gaps in our knowledge of grapevine downy mildew for improved forecasting and management. Plant Health Progress. Online publication. doi:10.1094/PHP-2007-0726-03-RV.

33. Jeger, M. J. 1999. Improved understanding of dispersal in crop pest and disease management: Current status and future directions. Agric. For. Meteorol. 97:331-349.

34. Lafon, R., and Clerjeau, M. 1988. Downy mildew. Pages 11-13 in: Compendium of Grape Diseases. R. C. Pearson and A. C. Goheen, eds. American Phytopathological Society, St. Paul, MN.

35. Madden, L. V. 1992. Rainfall and the dispersal of fungal spores. Pages 3979 in: Advances in Plant Pathology, Vol. 8, Academic Press, New York.

36. Madden, L. V., Hughes, G., and Ellis, M. A. 1995. Spatial heterogeneity of the incidence of grape downy mildew. Phytopathology 85:269-275.

37. Madden, L. V., Yang, X., and Wilson, L. L. 1996. Effects of rain intensity on splash dispersal of Colletotrichum acutatum. Phytopathology 86:864874

38. Magarey, P. A., Maelzer, D. A., Kable, P. F., Woods, P., Wicks, T. J., and Wallace, H. R. 1983. A management system for grapevine downy mildew in Australia-its conception. Pages 74-75 in: 4th Int. Congr. Plant Pathol. Melbourne, VIC, Australia.

39. Magarey, P. A., Wachtel, M. F., Weir, P. C., and Seem, R. C. 1991. A computer-based simulator for rational management of grapevine downy mildew (Plasmopara viticola). Plant Prot. Q. 6:29-33.

40. Park, E. W., Seem, R. C., Gadoury, D. M., and Pearson, R. C. 1997. DMCAST: A prediction model for grape downy mildew development. Vitic. Enol. Sci. 52:182-189.

41. Pruppacher, H. R., and Klett, J. D. 1980. Microphysics of Clouds and Precipitation. D. Reidel Publishing Co., Dordrecht, The Netherlands.

42. Ristaino, J. B., and Gumpertz, M. L. 2000. New frontiers in the study of dispersal and spatial analysis of epidemics caused by species in the genus Phytophthora. Annu. Rev. Phytopathol. 38:541-576.

43. Rosa, M., Genesio, R., Gozzini, B., Maracchi, G., and Orlandini, S. 1993. Plasmo: A computer program for grapevine downy mildew development forecast. Comput. Electron. Agric. 9:205-215.

44. Rossi, V., and Caffi, T. 2007. Effect of water on germination of Plasmopara viticola oospores. Plant Pathol. 56:957-966.

45. Rossi, V., Caffi, T., Bugiani, R., and Dellavalle, D. 2008. Estimating the germination dynamics of Plasmopara viticola oospores using the hydrothermal time. Plant Pathol. 57:216-226.

46. Rossi, V., Caffi, T., Giosuè, S., and Bugiani, R. 2008. A mechanist model simulating primary infections of downy mildew in grapevine. Ecol. Model. 212:480-491.

47. Rossi, V., Giosuè, S., and Caffi, T. 2009. Modelling the dynamics of infections caused by sexual and asexual spores during Plasmopara viticola epidemics. J. Plant Pathol. 91:615-627. 
48. Rumbou, A., and Gessler, C. 2004. Genetic dissection of a Plasmopara viticola population from a Greek vineyard in two consecutive years. Eur. J. Plant Pathol. 110:379-392.

49. Seem, R. C., Magarey, P. A., McCloud, P. I., and Wachtel, M. F. 1985. A sampling procedure to detect grapevine downy mildew. Phytopathology 75:1252-1257.

50. Strizyk, S. 1983. Modèle d'état potentiel d'infection. Application a Plasmopara viticola. ACTA, Paris.

51. Ulbrich, C. W. 1983. Natural variations in the analytical form of the raindrop distribution, J. Clim. Appl. Meteorol. 22:1764-1775.

52. Venette, R. C., Moon, R. D., and Hutchison, W. D. 2002. Strategies and statistics of sampling for rare individuals. Annu. Rev. Entomol. 47:143-174.

53. Vercesi, A. 1995. Considerazioni sull'applicazione di modelli epidemici a
Plasmopara viticola (Berk. et Curt.) Berl. e de Toni. Riv. Patol. Veg. 5:99-111.

54. Walklate, P. J. 1989. Vertical dispersal of plant pathogens by splashing. Part I. the theoretical relationship between rainfall and upward rainsplash. Plant Pathol. 38:56-63.

55. Walklate, P. J., McCartney, H. A., and Fitt, B. D. L. 1989. Vertical dispersal of plant pathogens by splashing. Part II: Experimental study of the relationship between raindrop and the maximum splash height. Plant Pathol. 38:64-70.

56. Yang, X., Madden, L. V., Reichard, D. L., Wilson, L. L., and Ellis, M. A 1992. Splash dispersal of Colletotrichum acutatum and Phytophthora cactorum from strawberry fruit by single drop impactions. Phytopathology 82:332-340. 